\title{
THE USE OF BOOKS IN CONTENT AND LANGUAGE INTEGRATED LEARNING (CLIL)
}

\author{
Veronika Bežilová \\ Institute of British and American Studies, Faculty of Arts, University of Prešov, Slovakia
}

\begin{abstract}
Connection between language and content in school environment is important, especially when we teach our students to be independent language users. The present paper investigates the connection between language and content goals. Research sample consisted of 10 and 11 years old primary school students $(N=12, M=1, F=11)$. The research was focused on the book Your Body, where vocabulary connected to body was being taught. New vocabulary was presented in the context, afterwards, new vocabulary and phrases were being thought through the mind maps. The case study approach was used to get an in-depth analysis of the research problem. The main aim of the research was to connect language and content, where the main emphasis was put on the content. The paper answers the research question focused on the role of the books in language and content integrated learning. The results of the research show that books are a great connection between language and content goals and can be used in content and language integrated learning.
\end{abstract}

Keywords: book, content, language, your body.

\section{Introduction}

Nowadays more and more educational facilities are trying to modernise teaching process which is supported by Z. Lukáčová's (2017, p. 29) claim that "over the past decade, there has been an increasing interest in the incorporation of technology in foreign teaching and learning"; however, there is another way how schools try to modernise teaching of foreign languages, by usage of CLIL (content and language integrated learning) methodology. In general, CLIL is described as "using a language that is not a student's native language as a medium of instruction and learning for primary, secondary and/or vocational-level subject such as maths, science, art or business” Mehisto et al., 2008 which is in agreement with Z. Straková's (2013, p. 9) statement of the main purpose of CLIL, which is to integrate "other school subjects or areas into teaching English." Books are one of the most widely known sources of information. Books are used for different purposes, books can be read for entertainment or as a source of knowledge and they can also help to develop language skills, regardless of learner's age. Therefore, books represent an excellent connection between language and content. There are two ways how can CLIL be integrated into the learning and 
teaching process. Z. Straková (2011, p. 5) claims "it can weave into the content subject with the focus on learning and language skills or vice versa through the foreign language lessons focusing on the content areas as well as learning skills.”

The present study aims to investigate the usage of books in CLIL and its connection between language and content goals. The main aim of the case study is to analyse the influence of the books in CLIL and how they support development of language skills. The case study was applied to get an in-depth analysis of the given phenomenon and answers the research question focused on the role and importance of books in content and language integrated learning. Main research method was observation and the research study was based on ethnographic approach, as the researcher was not only observing, but also interacting with the students. The study focuses on books as they provide both content and language; therefore, they represent a valuable tool for connection of content and foreign language.

\section{Literature review}

The current research offers different ways of how can CLIL be applied and used in schools. Urmeneta (2019) claims that the term CLIL is an umbrella term and it covers educational programmes for non-native speakers, who are being taught disciplinary content through the second language. Urmeneta (2019, p.9) claims that "Content and Language Integrated Learning (CLIL) is a plurilingual approach to learning and teaching in formal contexts. Researchers as Coyle, Hood \& Marsch (2010), and Dalton-Puffer (2011) agree with Urmenenta' (ibid) definition of CLIL. Urmeneta (ibid) also focuses on the classroom interaction in CLIL educational environment, the results of the research show that there is an increase of contact time with the second language, but also in the quality of interaction, when compared to the standard foreign language classroom. Pavelová (2016, p. 94) adds that "communication if the glue that holds people together; it makes connection and interaction between people possible." Communication in the classroom, especially in CLIL classroom, is important as it brings real-life situations to teaching and students can use gained vocabulary.

Authors (Urmeneta, 2019; Coyle, Hood, \& Marsh, 2010; Dalton-Puffer, 2011; Craen, Mondt, Allain, \& Gao, 2007) agree that there are dual aims in CLIL, which promote language learning and linguistic diversity. Danica Gondová (2013) points out that CLIL has two different aims: language goals and content goals, which is also supported by Marsh (2002, p. 65) who defines CLIL as "dualfocused methodological approach that embraces both language and non-language content”. Authors, who focus on CLIL define this phenomenon differently; therefore, there are also different ways how can be CLIL applied in the educational environment. Throughout the world, different subjects are being 
taught through the foreign language and it depends on the school's conditions, mainly on the teachers. There is also a difference between the number of schools devote to foreign language - it varies from a few lessons a day to a few lessons a week (Gondová, 2013).

Straková (2011) focuses her research on the integration of art into foreign language teaching. The results of the research show that CLIL oriented activities supported students' performance; moreover, the results show that language proficiency of students does not limit their performance. Suwannoppharat and Chinokul (2015) add that successful CLIL lessons depend on both, enthusiastic teachers and students; therefore, CLIL classes should be carefully planned. Xanthou (2011) realised two small-scale experiments, which focused on the development of L2 vocabulary when supported by CLIL. The results demonstrated a significant difference between experimental groups and control groups, where experimental groups significantly outperformed control groups.

The research, primarily focused on teachers, of M. Sepešiová (2015) aims to raise the awareness of the importance of materials in planning CLIL lessons. The research shows that education of teachers within CLIL is very important, the author claims that "a teacher who is unfamiliar with CLIL methodology has problems using already prepared materials with activities and tasks correctly" (Sepešiová 2015, p. 1). M. Sepešiová (ibid) also claims that there are several problematic areas as language competencies or statement of content objective concerning the preparation of CLIL lesson. I. Cimermanová (2017, p.12) adds that "No sufficient teacher with training in CLIL methodology in one of the cardinal problems but it is not insoluble".

Even though there are some problematic areas within the preparation of CLIL lesson, the available research serves as evidence that well prepared and designed CLIL classes are effective when planned with regards to students' needs. However, there are is only small research focused on the books as a unifying element for content and language integrated learning; therefore, the following research focuses on the usage books in CLIL.

\section{Methodology}

The research was realized at private language school and research participants were eleven and twelve years' old students $(\mathrm{N}=12, \mathrm{M}=1, \mathrm{~F}=11)$. For this research case study approach was applied. The main focus of the research was at the books and their usage in CLIL. English lessons were managed and taught by the researcher. The main research tools were tests, observation, and group interviews.

The research tries to answer following research questions: What is the role of books in CLIL? Following assumption emerged from the research questions: 
Books are a great connection between the content and language, and they proved to be a valuable teaching tool in CLIL.

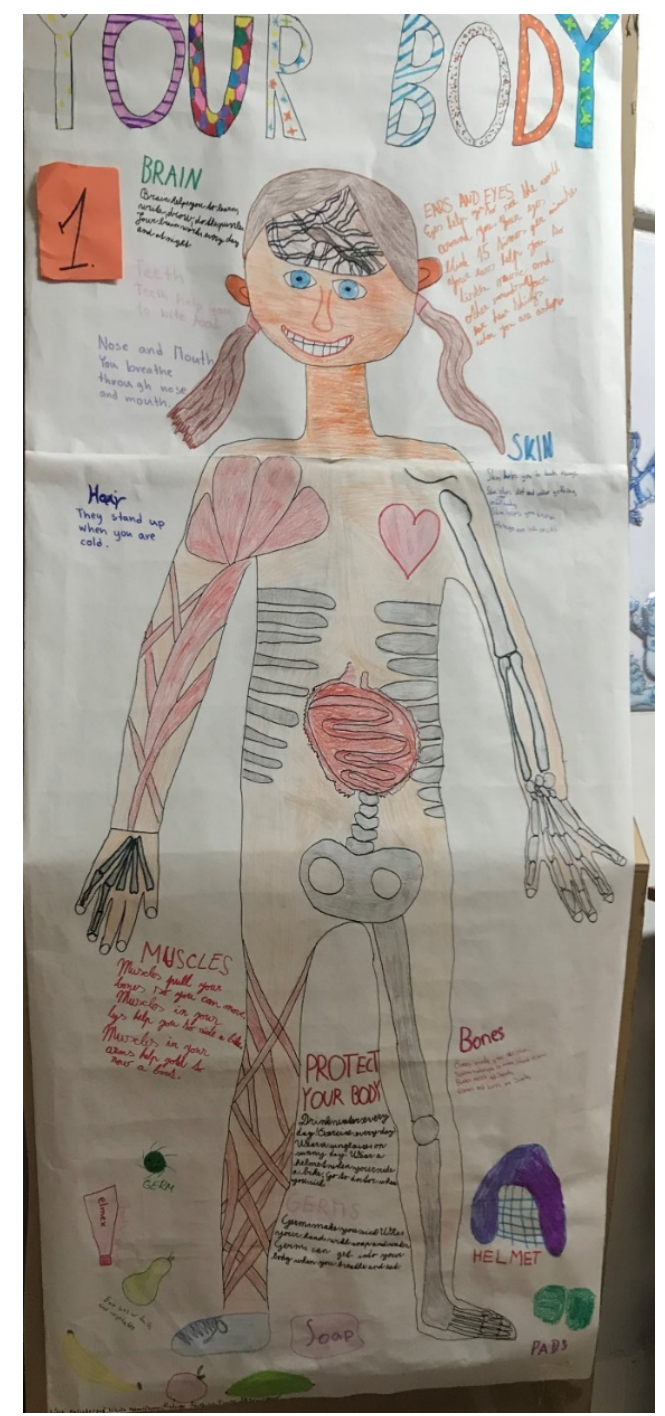

Figure 1 Project - Your Body, group 1

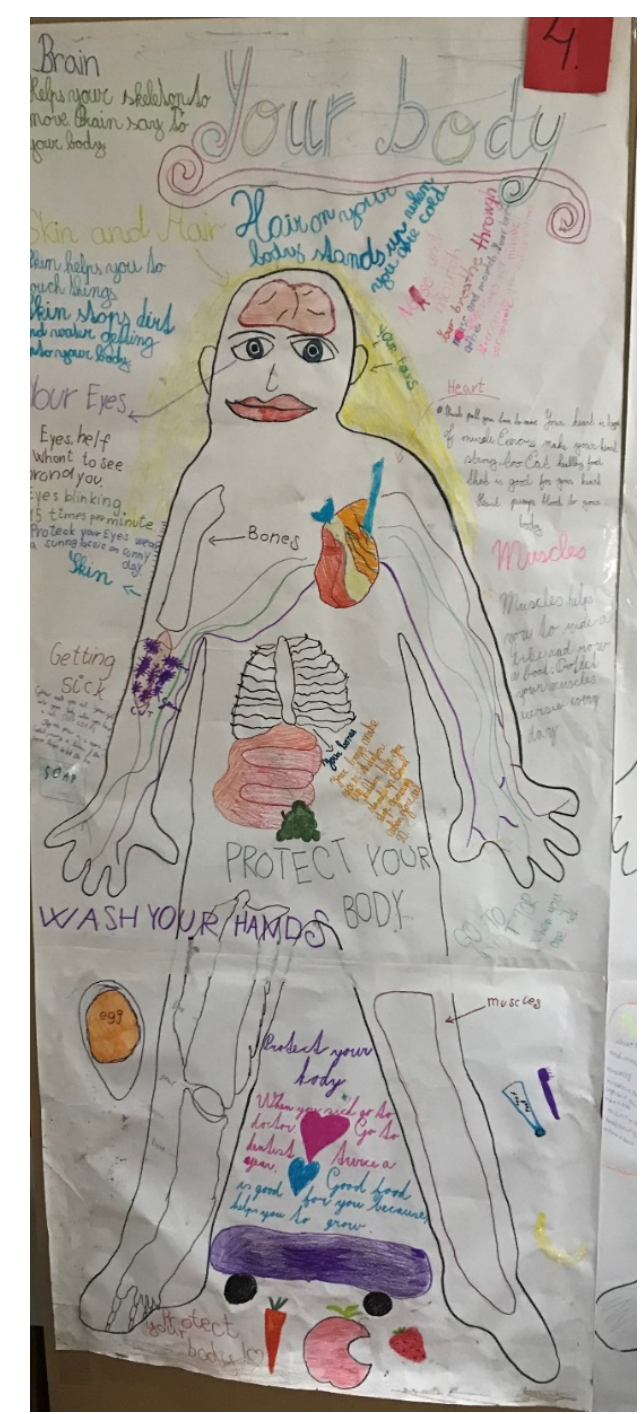

Figure 2 Project - Your Body, group 2

The following case study aims to investigate the role of the books in CLIL. It describes an example of the usage of how biology books can be used in foreign language classes. The case study lasted 12 weeks (60 minutes per week).

The main aim of every lesson was to get more familiar with not only target vocabulary, but also the content which was drawn from the biology. The book was not an authentic material, the book that matched students' level of proficiency was used. Every week, students read about a different part of the human body; afterwards, the topic was discussed and researcher together with the students chose the most important information from the topic and made the mind map. The following lesson was focused on the revision of the previous topic, different types 
of revision were used. The revision was administered through retelling the mind maps, rewriting the mind map, or completion of the mind map.

There was a test after every two topics were discussed and summarized. The tests were focused on the vocabulary, as well as, students' ability to use gained vocabulary in a meaningful context. The procedure of eleven lessons was the same, the twelfth week was dedicated to the poster making. Students were making a poster under the one condition, they were not allowed to use any book or notes. Students made the poster only with the knowledge they gained during the eleven weeks. There were five groups (the same age) of children who made the posters, but only two of them (see figure 1 and figure 2) were taught by the researcher. Language classes focused on the topic Your Body ended with a big competition, where all language school students took the vote.

\section{Research results}

The analysis of the projects and observation notes showed that that books provide students with the content, which enable them to see the vocabulary in its natural environment. The observation showed that students were engaged throughout the reading and mind-map making, as they debated the main of mind maps and they were also focused during the reading. It was also observed that talking about the content and subsequent mind-map making supported the development of critical thinking of students, because with every next mind-map they were able to choose the most relevant information.

After the poster making, students supported the fact that books are helpful learning tool and they expressed that it was easier for them to learn new vocabulary when they saw them in sentences. One of the students also expressed that the pictures that were provided in the books helped him a lot when he was learning new vocabulary. The results of the research show that books play an important role in CLIL and therefore the assumption about the case study can be confirmed. It was also observed that students enjoyed project creation and it also supported their ability to work together as one group. The students also expressed that they would like to read another book in the same way Your Body was read.

The research question was focused on the role of the books in CLIL. As it is already mentioned, books provide students with both content and pictures, both of which are helpful throughout the learning process. Books provide teachers with the perfect connection of both language and content; moreover, the teacher can choose books according to his/her students' language proficiency. 


\section{Conclusions}

This paper investigated the role of the books in the Content and Language Integrated Learning and it has given an example of how teacher can use books in CLIL and overcome the stereotype. Throughout the realization of the case study, the researcher tried to monitor students' motivation engagement in foreign language classes. Integration of biology and English language broaden not only the vocabulary, but it also awakened students' motivation to learn new words in the English language. Students expressed that English language classes were meaningful, as they were learning words, phrases and sentences which they can use in real-life situations.

This case study also supports above-mentioned authors and their claim that CLIL is a powerful tool, and its support not only teaching but also learning process. It is not enough to teach students of foreign language new words; therefore, content is important and the connection between language and content are books. Research also supports the benefits of the integration of language and content which results in books.

It is recommended for the future research to compare two groups, experimental and control group, where one group will be using books on CLIL lessons and the second will be taught without books. The results will demonstrate whether it is enough to prepare well planned CLIL lessons, and what the contribution of books to CLIL is.

\section{Acknowledgement}

This study derived from a governmentally-funded research project financed by the Slovak Ministry of Education, Science, Research and Sport (research grant number KEGA project No. 032PU-4/2019, project: Vytvorenie učebných materiálov pre učitel'ov základných škôl pre integrovanie jazykového a obsahového vyučovania).

\section{References}

Coyle, D., Hood, P., \& Marsh, D. (2010). CLIL: Content and Language Integrated Learning. Cambridge University Press

Craen, P., Mondt, K., Allain, L., \& Gao, Y. (2007). Why and How CLIL Works. An Outline for a CLIL Theory. CLIL Special Issue, 16(3), 70-78.

Dalton-Puffer, C. (2011). Content and Language Integrated Learning: From Practice to Principles? Annual Review of Applied Linguistics, 31, 182-204.

Gondová, D. (2013). CLIL - integrované vyučovanie obsahu a jazyka. Žilina: EDIS vydavatel'stvo Žilinskej univerzity. 
Proceedings of the International Scientific Conference. Volume III, May $22^{\text {th }}-23^{\text {th }}, 2020.66-72$

Lukáčová, Z. (2017). On the nature of the implementation steps towards blended learning in teacher training programmes. CLEaR2017 conference proceedings, 23-38.

Marsh, D. (2002). CLIL/EMILE: The European dimension: actions, trends and foresight potential. Jyväskylä: UniCOM.

Mehisto, P., Marsh, D., \& Frigols, M.J. (2008). Uncovering CLIL: Content and Language Integrated Learning in Bilingual and Multilingual Education. Macmillan

Pavelová, B. (2016). On communication, social roles, register and teaching. English Matters, 7, 93-103.

Sepešiová, M. (2015). Materials in CLIL classes. CLE2015 conference proceedings. Retrieved from https://www.slovakedu.com/publications/llce2015-conference-proceedings/a20/

Straková, Z. (2011). Integrating Art into Teaching English at a Primary Level: A Case Study. In A. Kačmárová (Ed.), English Matters II., (pp. 75-81). Prešov: Prešovská univerzita v Prešove.

Straková, Z. (2013). Introduction to Teaching English as a Foreign Language. Prešov: Vydavatel'stvo Prešovskej Univerzity.

Suwannoppharat, K., \& Chinokul, S. (2015). Applying CLIL to English Language Teaching in Thailand: Issues and Challenges. LACLIL, 8(2), 237-254.

Urmeneta, C.E. (2019). An Introduction to Content and Language Integrated Learning (CLIL) for Teachers and Teacher Educators. CLIL Journal of innovation and research in Plurilingual and Pluricultural Education, 2(1), 7-9. Retrieved from https://doi.org/10.5565/rev/clil.21

Xanthou, M. (2011). The impact of CLIL on L2 vocabulary development and content knowledge. English Teaching: Practice and Critique, 10(4), 116-126.

Cimermanová, I. (2017). CLIL - a Dialogue between the Language and Subject Teacher. Scientia Et Eruditio, 1, 1-14. 